\title{
Supplemental polyethylene glycol influences preferences of goats browsing blackbrush
}

\author{
CHRISTOPHER H. TITUS, FREDERICK D. PROVENZA, AVI PEREVOLOTSKY, NISSIM SILANIKOVE, AND \\ JOZO ROGOSIC
}

Titus and Provenza are research assistant and professor, respectively, Department of Rangeland Resources, Utah State University, Logan, Ut, USA 843225230. Perevolotsky and Silanikove are research scientists with the Volcani Center, P.O. Box 6, Bet Dagan, Israel 50250. Rogosic is a research scientist with the Institute for Adriatic Crops and Karst Reclamation,Put Duilova, 21000 Split, Croatia.

\begin{abstract}
Supplemental polyethylene glycol (PEG) increases intake of foods high in tannins, but it is not known if PEG affects preference when herbivores forage on a variety of foods that differ in concentrations of macronutrients and tannins. We investigated how macronutrients, tannins, and PEG affected preferences of goats (Caprus hircus) for current season's and older growth twigs from the shrub blackbrush (Coleogyne ramosissima Torr.). In blackbrush, current season's twigs are higher than older twigs in macronutrients, but goats prefer older twigs because high levels of tannins in current season's twigs decrease preference. We conducted a pen trial and a paddock trial. During the 7-day pen trial, goats were offered current season's twigs and older twigs throughout the day. Eight goats were supplemented with $20 \mathrm{~g}$ PEG mixed with 100 g ground alfalfa (Medicago sativa $L$.) pellets, and 8 goats were supplemented with $100 \mathrm{~g}$ ground alfalfa pellets. Goats supplemented with PEG ate more current season's twigs than goats that did not receive PEG $(P=0.04)$. During the 17-day paddock trial, 10 goats were supplemented with 50 g PEG mixed with ground alfalfa/barley (Hordeum vulgare $\mathrm{L}$.), and 10 goats were supplemented with ground alfalfa/barley. Goats supplemented with PEG preferred current season's to older twigs, whereas PEG-unsupplemented goats preferred older to current season's twigs $(P=\mathbf{0 . 0 0 0 1})$. Goats had equal preference for juniper (Juniperus osteosperma Torr.) trees $(P=0.243)$. Collectively, our findings show that supplemental PEG can change food preferences.
\end{abstract}

Key Words: tannins, macronutrients, intake, shrubs

Tannins suppress intake by reducing digestibility or causing illness. Tannins bind to cell walls and cell solubles (Kumar and Vaithiyanathan 1990, Reed 1995), and in the process reduce digestion of protein and energy-rich volatile fatty acids (Robbins et al. 1987, Makkar et al. 1995). This in turn adversely affects preference (Villalba and Provenza 1996, 1997a, 1997b, 1997c, 1999). Tannins also produce aversive postingestive effects that are best accounted for by lesions of gut mucosa and toxicity

This research was supported by grants from the Binational Agricultural Research and Development Fund (BARD) and the Utah Agricultural Experiment Station. This paper is published with the approval of the Director, Utah Agricultural Experiment Station, Utah State University as Journal paper number 7186.

Manuscript accepted 13 Jun. 2000

\section{Resumen}

El polietilen glicol (PEG) suplementario incrementa el consumo de alimentos con altos contenidos de taninos, pero no se sabe si el PEG afecta la preferencia cuando los herbívoros se alimentan en una variedad de alimentos que difieren en la concentración de macronutrientes y taninos. Investigamos como los macronutrientes, taninos y PEG afectaron la preferencia de las cabras (Capra hircus) por el crecimiento del año y el crecimiento viejo de ramas de arbustos de "Blackbrush" (Coleogyne ramosissima Torr.). En "Blackbrush", el crecimiento nuevo de las ramas tiene un mayor contenido de macronutreientes que el crecimiento viejo, pero las cabras prefieren el crecimiento viejo debido a que el alto contenido de taninos del crecimiento nuevo disminuye la preferencia. Conducimos un experimento en corral y uno en potrero. Durante los 7 días del ensayo en corral, a través del día, se les ofreció a las cabras remas de crecimiento nuevo y ramas de crecimiento viejo. 8 cabras se suplementaron com 20 g de PEG mezclados con $100 \mathrm{~g}$ de pelets de alfalfa (Medicago sativa $\mathrm{L}$.) molida y 8 cabras se suplementaron con $100 \mathrm{~g}$ de pelets de alfalfa molida. Las cabras suplementadas con PEG comieron mas ramas de crecimiento nuevo que las cabras que no recibieron PEG $(P=0.04)$. Durante los 17 días del ensayo en el potrero, 10 cabras se suplementaron con $50 \mathrm{~g}$ de PEG mezclados con alfalfa/cebada molidas (Hordeum vulgare L.) y 10 cabras se suplementaron solo con alfalfa/cebada molidas. Las cabras suplementadas con PEG prefirieron las ramas de crecimiento nuevo sobre las de crecimiento viejo, mientras que las que no se suplementaron con PEG prefirieron las ramas de crecimiento viejo $(P=$ 0.0001). Las cabras tuvieron igual preferencia por árboles de "Juniper" (Juniperus osteosperma Torr.). Nuestros hallazgos muestran que el PEG suplementario puede cambiar la preferencia por los alimentos.

(Kumar and Singh 1984, Provenza et al. 1990, 1994, Reed 1995). Supplemental polyethylene glycol (PEG) binds to tannins, and increases intake of high-tannin foods by sheep (Barry 1985, Pritchard et al. 1988, Silanikove et al. 1994, Gilboa 1995), goats (Silanikove et al. 1996), and cattle (Hannigan and McNeill 1998). Despite these promising results, it is not known if PEG changes food preferences when animals eat a variety of foods that differ in concentrations of macronutrients and tannins. We investigated how macronutrients, tannins, and PEG affected preference for current season's and older growth twigs of the shrub blackbrush (Coleogyne ramosissima Torr.) by goats (Caprus hircus). In 
blackbrush, current season's twigs are higher than older twigs in macronutrients, but goats prefer older to current season's twigs because high levels of tannins decrease goats' preference for current season's twigs (Provenza et al. 1983a, 1983b, 1990, 1994).

\section{Materials and Methods}

We conducted a pen trial and a paddock trial. Both studies occurred on blackbrushdominated land in extreme southwestern Utah at $37.2^{\circ} \mathrm{N}, 113.5^{\circ} \mathrm{W}$ (for a detailed description of the site see Provenza et al. 1983a, 1983b). The elevation of the study site is $1,280 \mathrm{~m}$. The soils are loams underlain by a petrocalcic horizon at roughly 1 $\mathrm{m}$ depth. The dominant vegetation is blackbrush with scattered juniper (Juniperus osteosperma Torr.) trees.

\section{Pen Trial}

The objective of the pen trial was to compare intake of current season's and older twigs by goats supplemented or not with PEG. During October of 1994, we conducted a trial where goats were confined to individual pens $(3 \mathrm{~m} \mathrm{x} 3 \mathrm{~m})$ adjacent to one another. Sixteen Spanish goats (adult females $46 \mathrm{~kg}$ ) were stratified by weight and then randomly assigned to treatments. Eight goats received 20 g PEG mixed with $100 \mathrm{~g}$ of ground alfalfa (Medicago sativa L.) pellets, and 8 goats received $100 \mathrm{~g}$ of ground alfalfa pellets. Every goat ate all of its supplement immediately after it was offered each day. All goats were then fed $300 \mathrm{~g}$ each of current season's and older twigs in separate food boxes from 0900 to 1600 hours daily for 7 days; we collected and weighed refusals each evening. Blackbrush was harvested with clippers and then ground to $3 \mathrm{~cm} \mathrm{seg-}$ ments in a brush shredder.

\section{Paddock Trial}

The objective of the paddock trial was to determine the influence of supplemental PEG on preference of goats for current season's and older blackbrush twigs and juniper trees. To provide ample material for the comparison, a 1-ha paddock of blackbrush was clipped with gas-powered hedge trimmers during March of 1997 to stimulate production of current season's twigs. We clipped roughly one-half of the plants. Clipped and unclipped plants were interspersed throughout the paddock. We removed about 10 to $20 \mathrm{~cm}$ from the outer canopy of the blackbrush shrubs which were approximately $1 \mathrm{~m}$ in height. During the trial, goats had access to current season's twigs, older twigs, juniper trees and limited amounts of dried grasses and forbs that grew underneath blackbrush plants.

Twenty goats (wethers of mixed dairy breeds) were purchased at 4 to 6 weeks of age and reared at the Green Canyon Ecology Center, Logan, Utah during the summer of 1997. Goats foraged on an orchardgrass (Dactalis glomerata 0.)brome (Bromus inermis Leyss.) pasture, and they were group-supplemented every day at 0800 hours with ground barley (Hordeum vulgare L., $400 \mathrm{~g}_{\text {goat }}{ }^{-1}$ ). They had access to trace mineral blocks and water ad libitum. Goats (32 kg) were transported to southern Utah for experiments with blackbrush in October of 1997.

Before leaving Logan, goats were separated into 2 groups (10/group) and familiarized with the supplementation procedure. One group received $50 \mathrm{~g}$ of ground barley/alfalfa each morning at 0700 hours for several days. The other group was supplemented $\left(100\right.$ g goat $\left.^{-1}\right)$ with a mixture of ground barley/alfalfa and PEG (50\% barley/alfalfa, 50\% PEG). Although others have successfully used $25 \mathrm{~g}$ of PEG as a supplement for animals eating foods high in tannins (Silanikove et al. 1994), we supplemented lambs with $50 \mathrm{~g}$ of PEG each morning in order to ensure that animals received enough PEG to attenuate the effects of blackbrush tannin.

From about 0730 to 1700 hours daily for 17 days in October, goats were allowed to forage in the 1-ha paddock. Each evening at about 1700 hours, PEG-supplemented and PEG-unsupplemented goats were herded into separate pens. Each morning at 0700 hours, 10 goats were fed PEG (50 $\mathrm{g}$ animal ${ }^{-1}$ ) mixed with ground barley and ground alfalfa pellets, while the other 10 goats were given only the ground barleyalfalfa. Ample food boxes were provided so that all goats could ingest supplement, and all supplement was consumed within $30 \mathrm{~min}$. Goats had free access to fresh water and trace mineral blocks while in pens and while foraging in the paddock.

The amount of barley and alfalfa fed was reduced as the trial proceeded in an attempt to determine if barley-alfalfa

Table 1. Supplement provided per goat during the paddock trial.

\begin{tabular}{cll}
\hline \hline Days & No supplemental PEG & Supplemental PEG \\
\hline 1 to 7 & $200 \mathrm{~g}$ alfalfa/barley & $200 \mathrm{~g}$ alfalfa/barley, 50 g PEG \\
8 to 11 & $100 \mathrm{~g}$ alfalfa/barley & $100 \mathrm{~g}$ alfalfa/barley, 50 g PEG \\
12 to 15 & $50 \mathrm{~g}$ alfalfa/barley & $50 \mathrm{~g}$ alfalfa/barley, 50 $\mathrm{g} \mathrm{PEG}$ \\
16 to 17 & $0 \mathrm{~g}$ alfalfa/barley & $200 \mathrm{~g}$ alfalfa/barley, 50 g PEG \\
\hline
\end{tabular}

affected preference for blackbrush twigs (Table 1). The PEG supplemented group was given the same barley-alfalfa mix during periods 1 and 4, whereas the PEGunsupplemented group did not receive any barley-alfalfa supplement in period 4 (Table 1).

Shortly after being supplemented each morning, goats were released into the paddock and 2 observers recorded the incidence of eating current season's twigs, older twigs, and juniper. We visually scanned and recorded what each goat was eating at 3-minute intervals for 1 hour (Altmann 1974). Each goat had a number painted on its side to enable data collection by the observer. Goats ate avidly throughout the 1-hour period, so we typically recorded 20 observations hour ${ }^{-1}$ of foraging for each goat. Goats were allowed to forage in the paddock from about 0730 hours until 1700 hours daily.

\section{Statistical Analyses}

For the pen and paddock trials, the repeated measures analyses of variance had 2 treatments (PEG-supplemented and PEG-unsupplemented). Goats $(\mathrm{n}=8$ treatment $^{-1}$ in the pen trial and 10 treatment $^{-1}$ in the paddock trial) were nested within treatments. Plant part (current season's twigs and older twigs in the pen trial; current season's twigs, older twigs, juniper in the paddock trial) was treated as a splitplot in the analyses. Day ( $n=7$ in the pen trial and 17 in the paddock trial) was the repeated measure. Least significant differences $\left(\mathrm{LSD}_{.05}\right)$ were determined when Fratios were significant $(\mathrm{P}<0.05)$.

\section{Results}

\section{Pen Trial}

Intake of current season's twigs gradually increased throughout the 7-day trial (day effect $\mathrm{P}=0.0001$; Fig. 1). As intake increased from days 4 to 7 , PEG-supplemented goats ingested more current season's twigs than non-PEG supplemented goats (treatment $\mathrm{x}$ food interaction $\mathrm{P}=$ 0.040; Fig. 1). Intake of older twigs did not differ between treatments, though there was a consistent tendency for PEG-
$50 \mathrm{~g}$ alfalfa/barley, $50 \mathrm{~g}$ PEG 
supplemented goats to eat more older twigs than PEG-unsupplemented goats ( $\mathrm{P}$ $=0.211$; Fig. 1).

\section{Paddock Trial}

Goats supplemented with PEG ate more current season's twigs and less older twigs than non-PEG supplemented goats. Preference for current season's twigs by PEG-supplemented goats varied from dayto-day, especially during the first half of the trial; during the latter half of the trial, preference declined and was less variable (treatment $\mathrm{x}$ food $\mathrm{x}$ day interaction $\mathrm{P}=$ 0.0001; Fig. 2). Preference for current season's twigs by PEG-unsupplemented goats was lower during the first 6 days of the trial than on days 7 to 12 , and lower again from days 13 to 17 (Fig. 2). Preference for older twigs generally increased throughout the 17-day trial for PEG-supplemented goats, whereas it remained relatively constant for non-PEG supplemented goats (Fig. 2). There was little correlation between amount of supplemental alfalfa/barley offered and preference for current season's and older twigs by goats not supplmented with PEG. However, as the amount of alfalfa/barley supplement offered declined from days 8 to 15 , intake of current season's twigs decreased and intake of older twigs increased for PEGsupplemented goats.

Supplemental PEG did not affect use of juniper by goats $((\mathrm{P}=0.243$; Fig. 2$)$. Goat use of juniper fluctuated during the first half of the trial, but varied little thereafter.

\section{Discussion}

Results from both the pen and the paddock trials suggest that PEG enabled goats to eat more of the nutrient-rich current season's twigs, even though they were higher in tannin than older twigs. The preference by PEG-supplemented goats for current season's rather than older twigs is consistent with the finding that high tannin concentrations in current season's twigs are aversive to goats (Provenza et al. 1990, 1994), and supports the hypothesis that PEG reduced the aversive effects of tannins. Goats in both treatments were naive to blackbrush which accounts for their initially low intakes of current season's twigs and older twigs (Distel and Provenza 1991).

High preferences for current season's twigs by PEG-supplemented goats 1 day were followed by lower preferences the next day during the first half of the paddock trial. Intake of juniper was also cyclical during the first half of the study for

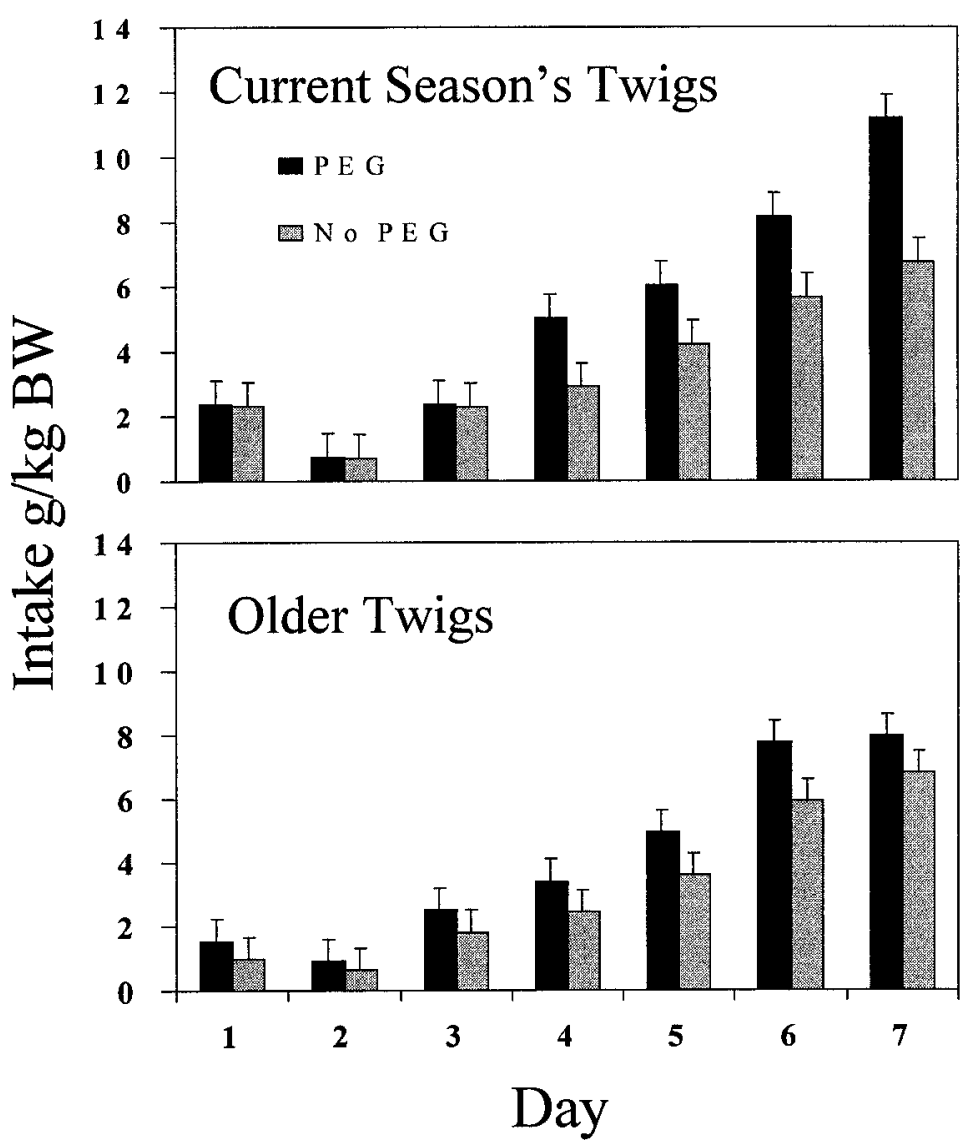

Fig. 1. Intake of current season's and older growth twigs of blackbrush by goats supplemented with $20 \mathrm{~g} \mathrm{day}^{-1}$ of polyethylene glycol (PEG) plus $100 \mathrm{~g}$ ground alfalfa pellets compared with PEG-unsupplemented goats fed only $100 \mathrm{~g}$ ground alfalfa pellets (bars represent standard errors; LSD $_{.05}=\mathbf{2 . 8}$ for current season's and 2.7 for older twigs).

both PEG-supplemented and PEG-unsupplemented goats. The daily variation decreased and eventually disappeared, which suggests that goats adjusted intake of current season's twigs to amounts they could tolerate as they became more experienced with both foods (Provenza et al. 1994). Similar cyclical patterns of intake, which occur when cattle ingest tall larkspur (Pfister et. al. 1997), are a result of interactions between the positive postingestive effects of macronutrients and the negative postingestive effects of compounds like alkaloids and tannins (Provenza 1995 1996). Cyclical patterns of preference for current season's twigs also suggest that $50 \mathrm{~g}$ of PEG did not completely attenuate the aversive effects of tannin. Depending on the chemical structure and the amount of tannin, higher amounts of PEG may be required to attenuate the effects of various tannins (Provenza et al. 2000).

Intake of current season's twigs by PEG-supplemented goats decreased when we reduced the amount of alfalfa/barley supplement on days 8 to 15 , and then began to increase when we again provided supplement on days 16 and 17. This observation is consistent with findings that supplemental macronutrients increase intake of foods high in toxins (Wang and Provenza 1996). Needs for macronutrients increase when animals ingest foods high in toxins (Foley et al. 1995, Illius and Jessop 1995), and additional macronutrients enable animals to ingest more of foods that contain compounds such as terpenes (Banner et al. 2000) and tannins (Villalba, unpublished data).

Though no tests were conducted to elucidate effects of social facilitation on food preferences, we attempted to minimize its effects by trimming blackbrush so that there was complete interspersion of clipped (current season's twigs) and unclipped (older twigs) plants throughout the paddock. Goats supplemented with PEG apparently experienced less aversive postingestive consequences from current season's twigs compared with non-PEG supplemented goats, which would cause 


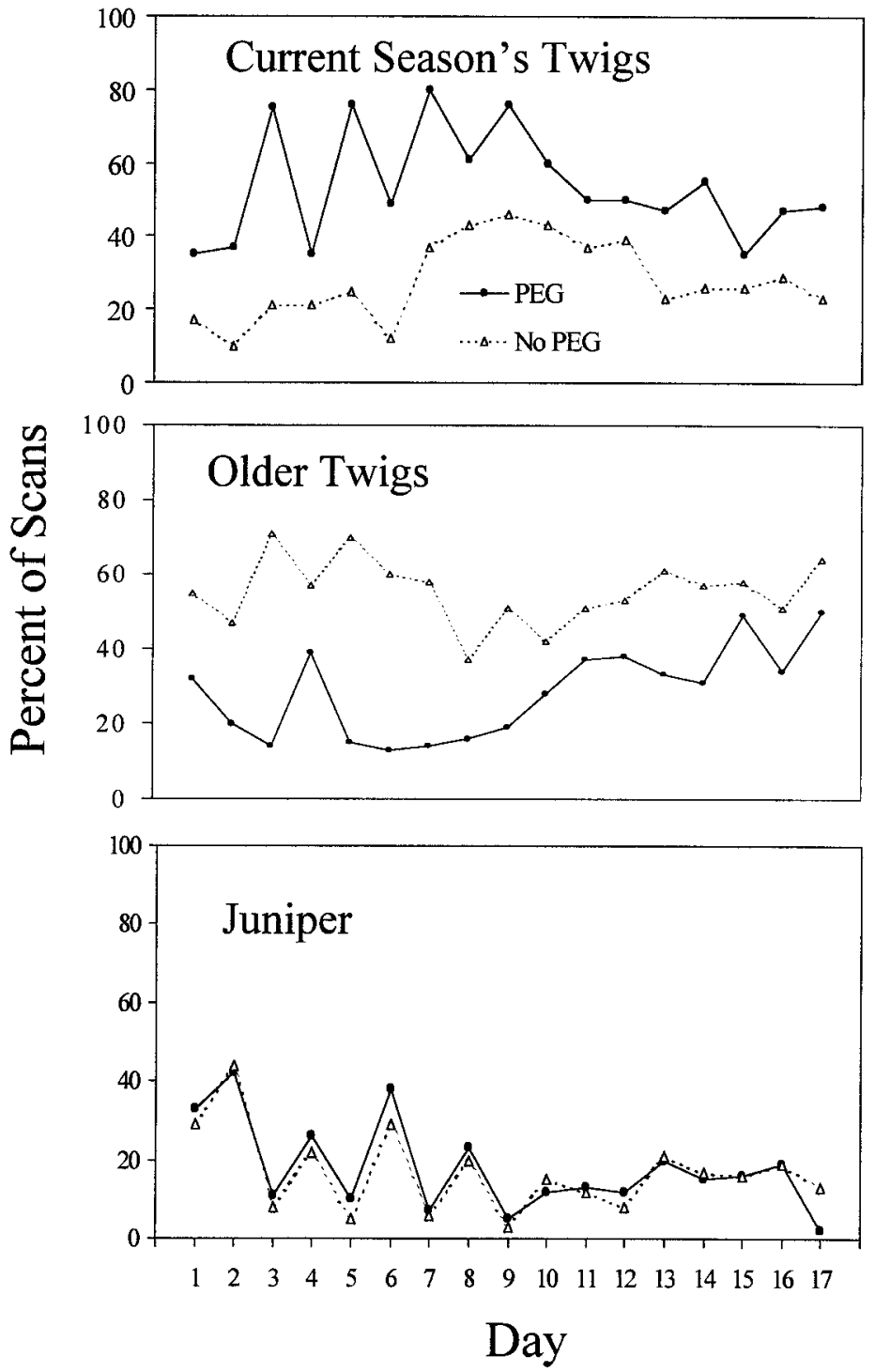

Fig. 2. Frequency of eating current season's and older blackbrush twigs and juniper by goats supplemented with $50 \mathrm{~g} \mathrm{day}^{-1}$ of polyethylene glycol (PEG) and PEG-unsupplemented (No PEG) goats during the paddock trial $\left(\mathrm{LSD}_{.05}=11\right)$.

their food preferences to differ from nonPEG supplemented goats, regardless of the social influences (Provenza et al. 1990, 1994). Lambs, for example, do not continue to eat foods with aversive postingestive consequences (i.e., when they experience toxicosis), even though their mothers avidly eat the foods (Provenza et al. 1993). Social interactions can facilitate behaviors, but continuation of the behaviors depends on the consequence to the individual.

\section{Conclusions}

Supplemental PEG might increase preferences of herbivores for tannin-rich forages which could lead to better animal production in areas dominated by tannincontaining species, and allow herbivores to more evenly use rangeland biomass. Supplemental PEG may also enable animals to better maintain fire breaks in areas dominated by plants high in tannins. Our findings are generally consistent with these notions. Results from both the pen and the paddock trials establish that PEGsupplemented goats preferred high-tannin food, whereas PEG-unsupplemented goats did not. While our findings are consistent with the hypothesis that PEG can change food preferences they warrant qualification. The effectiveness of supplemental PEG may be low if alternative forages are equal or superior in nutritional quality and contain less metabolites with aversive effects (Titus et al. 2000). In such cases, animals would likely prefer the alternatives to the high-tannin foods.

\section{Literature Cited}

Altmann, J. 1974. Observational study of behavior: sampling methods. Behav. 49:227-267.

Banner, R.E., J. Rogosic, E.A. Burritt, and F.D. Provenza. 2000. Supplemental barley and charcoal increase intake of sagebrush by lambs. J. Range Manage. 53:415-420.

Barry, T.N. 1985. The role of condensed tannins in the nutritional value of Lotus pedunculatus for sheep. 3. Rates of body and wool growth. Br. J. Nutr. 54:211-217.

Distel, R.A. and F.D. Provenza. 1991 Experience early in life affects voluntary intake of blackbrush by goats. J. Chem. Ecol. 17:431-450.

Foley, W.J., S. McLean, and S .J. Cork. 1995. Consequences of biotransformation of plant secondary metabolites on acid-base metabolism in mammals-A final common pathway? J. Chem. Ecol. 21:721-743.

Gilboa, N. 1995. The effects of PEG on the utilization of Mediterranean woody plants as forage for livestock. Ph.D. Thesis. Faculty of Agr, The Hebrew Univ., Jerusalem.

Hannigan, N.A. and D.M. McNeill. 1998. Cattle preference for two genotypes of fresh leucaena following the manipulation of their tannin content with polyethylene glycol. Anim. Prod. Aust. 22:401

Illius, A.W. and N.S. Jessop. 1995. Modeling metabolic costs of allelochemical ingestion by foraging herbivores. J. Chem. Ecol. 21:693-719.

Kumar, R. and Singh, M. 1984. Tannins, their adverse role in ruminant nutrition. J. Agr. Food Chem. 32:447-453.

Kumar, R. and S. Vaithiyanathan. 1990. Occurrence, nutritional significance and effect on animal productivity of tannins in tree leaves. Anim. Feed Sci. Tech. 30:21-38.

Makkar, H.P.S., M. Blummel, and K. Becker. 1995. Formation of complexes between polyvinyl pyrrolidones or polyethylene glycols and tannins, and their implications in gas production and true digestibility in in vitro techniques. Br. J. Nutr. 73:897-913.

Pfister, J.A., F.D. Provenza, G.D. Manners, D.R. Gardner, and M.H. Ralphs. 1997. Tall larkspur ingestion: can cattle regulate intake below toxic levels? J. Chem. Ecol. 23:759-777.

Pritchard, D.A., D.C. Stocks, B.M. O'Sullivan, P.R. Martins, I.S. Hurwood, and P.K. O'Rourke. 1988. The effect of polyethylene glycol (PEG) on wool growth and live weight of sheep consuming a Mulga (Acacia aneura) diet. Proc. Aust. Soc. Anim. Prod. 17:290-293.

Provenza, F.D. 1995. Postingestive feedback as an elementary determinant of food preference and intake in ruminants. J. Range Manage. 48:2-17. 
Provenza, F.D. 1996. Acquired aversions as the basis for varied diets of ruminants foraging on rangelands. J. Anim. Sci. 74:2010-2020.

Provenza, F.D., J.J. Lynch, and J.V. Nolan. 1993. The relative importance of mother and toxicosis in the selection of foods by lambs. J. Chem. Ecol. 19:313-323.

Provenza, F.D., J.J. Lynch, E.A. Burritt, and C.B. Scott. 1994. How goats learn to distinguish between novel foods that differ in postingestive consequences. J. Chem. Ecol 20:609-624.

Provenza, F.D., E.A. Burritt, A. Perevolotsky, and N. Silanikove. 2000. Self-regulation of intake of polyethylene glycol by sheep fed diets varying in tannin concentrations. J. Anim. Sci. in press.

Provenza, F.D., J.C. Malechek, P.J. Urness, and J.E. Bowns. 1983a. Some factors affecting twig growth in blackbrush. J. Range Manage. 36:518-520.

Provenza, F.D., J.E. Bowns, P.J. Urness, J.C. Malechek, and J.E. Butcher. 1983 b. Biological manipulation of blackbrush by goat browsing. J. Range Manage. 36:513-518.

Provenza, F.D., E.A. Burritt, T.P. Clausen, J.P. Bryant, P.B. Reichardt, and R.A. Distel. 1990. Conditioned flavor aversion: a mechanism for goats to avoid condensed tannins in Blackbrush. Amer. Nat. 136:810-828.
Reed, J.D. 1995. Nutritional toxicology of tannins and related polyphenols in forage legumes. J. Anim. Sci. 73:1516-1528.

Robbins, C.T., T.A. Hanely, A.E. Hagerman, o. Hjeljord, D.L. Baker, C.C. Schwartz, and W.W. Mautz. 1987. Role of tannins in defending plants against ruminants: reduction in protein availability. Ecol. 68:98-107.

Silanikove, N., Z. Nitsan, and A. Perevolotsky. 1994. Effect of a daily supplementation of polyethylene glycol on intake and digestion of tannin-containing leaves (Ceratonia siliqua) by sheep. J. Agr. Food Chem. 42:2844-2847.

Silanikove, N., N. Gilboa, I. Nir, A. Perevolotsky, and Z. Nitsan. 1996. Effect of a daily supplementation of polyethylene glycol on intake and digestion of tannin-containing leaves (Quercus calliprinos, Pistacia lentiscus and Ceratonia siliqua) by goats. J. Agr. Food Chem. 44:199-205.

Titus, C.H., F.D. Provenza, A. Perevolotsky, and N. Silanikove. 2000. Preferences for foods varying in macronutrients and tannins by lambs supplemented with polyethylene glycol. J. Anim. Sci. 78:1443-1449.

Villalba, J.J. and F.D. Provenza. 1996. Preference for flavored wheat straw by lambs conditioned with intraruminal administrations of sodium propionate. J. Anim. Sci. 74:2362-2368.
Villalba, J.J. and F.D. Provenza. 1997a. Preference for wheat straw by lambs conditioned with intraruminal infusions of starch. Br. J. Nutr. 77:287-297.

Villalba, J.J. and F.D. Provenza. 1997b. Preference for flavoured foods by lambs conditioned with intraruminal administration of nitrogen. Br. J. Nutr. 78:545-561.

Villalba, J.J. and F.D. Provenza. 1997c. Preference for flavored wheat straw by lambs conditioned with intraruminal infusions of acetate and propionate. J. Anim. Sci. 75:2905-2914.

Villalba, J.J. and F.D. Provenza. 1999. Nutrient-specific preferences by lambs conditioned with intraruminal infusions of starch, casein, and water. J. Anim. Sci. 77:378-387.

Wang, J. and F.D Provenza. 1996. Food deprivation affects preference of sheep for foods varying in nutrients and a toxin. J. Chem. Ecol. 22:2011-2021. 